\title{
Variation of Salinity in Batticaloa Lagoon in Sri Lanka During Wet Season
}

\author{
M. Sugirtharan ${ }^{*}$, S. Pathmarajah ${ }^{1}$ and M.I.M. Mowjood ${ }^{1}$ \\ Postgraduate Institute of Agriculture \\ University of Peradeniya \\ Sri Lanka
}

\begin{abstract}
Batticaloa lagoon occupies an area of $168 \mathrm{~km}^{2}$ in the eastern coast of Sri Lanka. Change in lagoon water salinity is an important aspect that affects the availability and composition of aquatic resources and the livelihoods of the people who are depending on these resources. In this view, lagoon water level, electrical conductivity (EC), salinity, $p H$ and temperature were continuously monitored at two locations, namely Kallady and Manmunaithurai, which are located $7.5 \mathrm{~km}$ apart. Readings were taken at weekly intervals during the wet season between September 2012 to March 2013. The lagoon water levels varied between 0.01 and $1.32 \mathrm{~m}$ above mean sea level (AMSL) at Kallady, which is located near the barmouth, whereas the variation at Manmunalthurai was between 0.15 and $1.54 \mathrm{~m}$. Corresponding salinity variation was from 37.5 to 3.5 ppt and 31.0 to 4.5 ppt at Kallady and Manmunaithurai, respectively. Surface water temperature at these two locations varied between $25.1^{\circ} \mathrm{C}$ to $30.6^{\circ} \mathrm{C}$ and the $\mathrm{pH}$ varied between a narrow range of 7.7 and 8.7. Salinity showed a highly significant decreasing trend with time ( $r=-0.693$ and $-0.71, p<0.01$ at Kallady and Manmunai area, respectively) during the rainy season. Similarly, a significant positive correlation was observed between the rainfall amount and the lagoon water height ( $r=0.782$ and $r=0.853, p<0.01$ at Kallady and Manmunai area, respectively). However, salinity showed no significant correlation with lagoon water height and the amount of rainfall. This may be due to the influence of tidal action on lagoon water salinity. The study revealed that a substantial variation in salinity occurs during a short period during the wet season and warrants further investigation on its influence on ecosystem and livelihoods.
\end{abstract}

Keywords: Batticaloa lagoon, salinity, water depth, ecosystem, livelihood

\section{INTRODUCTION}

The city of Batticaloa is located between the lagoon and the Indian Ocean in the east cost of Sri Lanka. Batticaloa district is flourished with three lagoons, namely Batticaloa, Valaichchenai and Vakarai. Among them, Batticaloa lagoon is the largest coastal water body in the District and it is a long and narrow lagoon and occupies an area of $168 \mathrm{~km}^{2}$ (Santharuban \& Manobawan, 2005). This lagoon is surrounded by a densely populated region used for cultivating rice, coconut and other field crops. The fishing community is depending on this lagoon for their income.

\footnotetext{
1 Department of Agricultural Engineering, Faculty of Agriculture, University of Peradeniya, Sri Lanka

Corresponding author: sugirtharan818@yahoo.com
} 
The system of lagoon is likely to consist various elements such as catchment area, ocean conditions and lagoon mouth characteristics. The effects of these various factors surrounding a lagoon would influence mixing processes. Those various phenomena occurring in the lagoon affect the social and economic activities around it. Conversely, various impacts by humans influence the coastal lagoon (Furusato et al,. 2012). Further, salinity and temperature of the water play an essential role in lagoon hydraulics which relates to lagoon productivity (Perera et al., 2013). Saline water intrusion is one of the important factors determining various physical, chemical, and ecological processes occurring in the water body. Depending on the local climatic conditions, lagoons which exhibit salinities may be changed from completely fresh to hypersaline. This is particularly true for the type of coastal lagoon, where the lagoon is connected to the coastal sea, at least intermittently, via a single channel and the tidal variability is largely filtered out during propagation of the tidal wave into the lagoon (Knoppers et al., 1991).

Batticaloa lagoon opens into the sea at two points. One in the southern end of the lagoon at Kallar and the other one is midway of the lagoon at Palameenmadu which is close to the Batticaloa town. Palameenmadu mouth is open most of the time but the other bar mouth at Kallar is usually opened only during rainy seasons. Saline water intrusion is the major event happening in the Batticaloa lagoon environment when the bar mouth is opened during the later part of the rainy seasons. It influences the type of fish catch and the groundwater quality of the adjacent areas. In addition, saline water intrusion is a major issue for paddy cultivation which is the second most important livelihood for the communities around the lagoon. If saline water intrusion is not managed or controlled, farmers will have to abandon the paddy cultivation and engage in alternative livelihoods. Therefore, it is important to study the variation of the lagoon water salinity during dry and wet seasons in order to utilize this water body efficiently and to prevent any adverse effects to the surrounding environment. In view of this, the present study was carried out during a rainy season to find the variation of salinity level of the lagoon as a preliminary step in preparing an integrated lagoon management plan.

\section{METHODOLOGY}

\section{Study site}

Batticaloa lagoon located between $7^{\circ} 24^{\prime}-7^{\circ} 46^{\prime} \mathrm{N}$, and $81^{\circ} 35^{\prime}-81^{\circ} 49^{\prime} \mathrm{E}$, is one of the most productive brackish water bodies in Sri Lanka (Fig. 1). More than $90 \%$ of the lagoon is located in Batticaloa District and the rest lies in Ampara District. Batticaloa lagoon is $56 \mathrm{~km}$ long (Shanmugaratnam, 1995) and extends from Kittangi/Kalmunai in Ampara District in the south to Pankudaweli in Batticaloa District in the north. Lagoon area receives about 1000$1700 \mathrm{~mm}$ of rainfall per annum, primarily (about 60\%) from the Northeast monsoon during October to February. It has a dry spell of five months from May to September. Winds are generally moderate, ranging from $7-15 \mathrm{~km}$ per hour with the evening winds being stronger. The main land use around the lagoon is agriculture and in particular paddy cultivation. Other land uses include urban areas, road networks, fresh water bodies adjoining the Batticaloa Lagoon, the Batticaloa Lagoon itself and associated vegetation such as mangrove. Lowest $(0.3 \mathrm{~m})$ and the highest $(6.5 \mathrm{~m})$ water depths have been recorded at the extreme northern region of the bar mouth. The maximum depth of the lagoon is about four meters (Scot, 1989) and the average water depth is around 1.5 m (MG Consultants, 2010). 


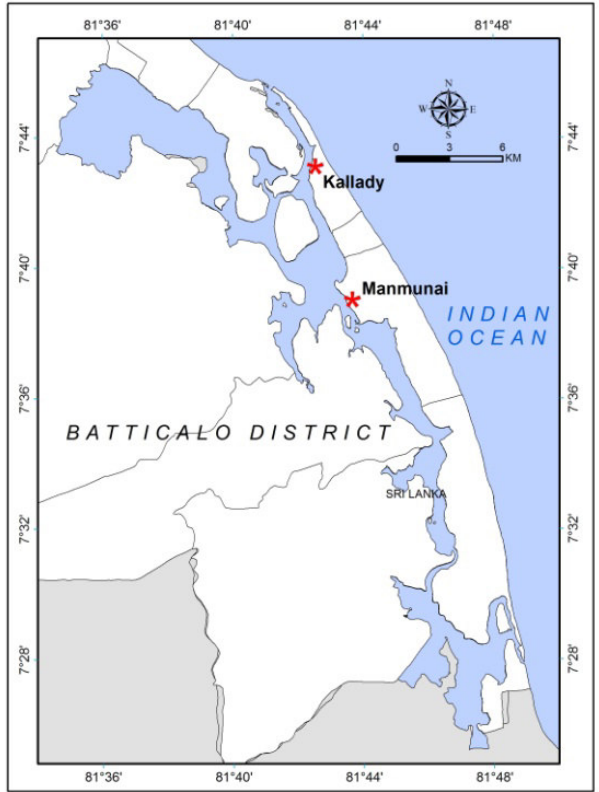

Fig. 1. Location of study area and the monitoring points (Kallady, Manmunai)

\section{Setting up of flood gauge}

In order to find the variation of lagoon water level, flood gauge (scales) were placed (Fig. 2) at two selected locations namely Kallady bridge and the Manmunai thurai area of the Batticaloa lagoon (Fig. 1). The distance between these two locations is about $7.5 \mathrm{~km}$. A temporary bench mark was established at the Kallady Bridge and Manmunaithurai connected to the Mean Sea Level (MSL) datum by leveling to a Survey Department Bench mark.

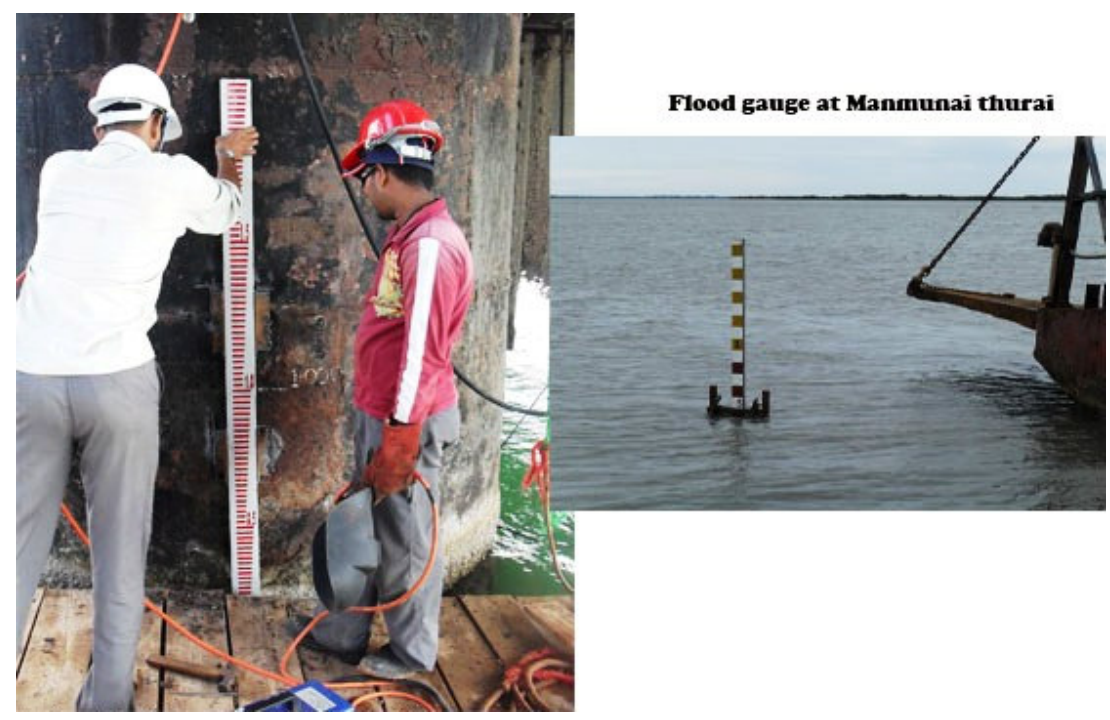

Fig. 2. Flood gauges at study locations 


\section{Water level monitoring and sampling}

In order to find the variation of the saline conditions of the lagoon during rainy days, water height of the lagoon in relation to MSL and the details of the daily rainfall data were collected in this study.

Lagoon water levels in relation to MSL were obtained from water level gauges fixed at two selected locations by direct observation. Readings were taken at weekly interval during rainy season of the year. At the same time, surface water samples from the lagoon were also collected and tested for quality parameters such as $\mathrm{pH}$, temperature, Electrical Conductivity (EC), Total Dissolved Solids (TDS) using a Portable pH/EC/TDS meter, and the salinity also was tested using Salinity Refractrometer. Three (03) samples were taken at one location at a time. These field observations and measurements were done in the field at weekly interval during the period between September 2012 and March 2013. Finally, results were statistically analysed using Minitab 14 software.

\section{RESULTS AND DISCUSSION}

\section{Water level variation and flood occurrence}

Water extent and water level are two essential information in flood monitoring and forecasting (Andreoli et al. 2007). Lagoon water height from MSL was recorded during the rainy season to find the relation of lagoon water height and the critical point for flood occurrence. Water depths at two locations at the time of installation of flood gauges were $1.01 \mathrm{~m}$ and $1.96 \mathrm{~m}$ at Manmunaithurai and Kallady bridge, respectively. Fig. 3 shows that the water height of the lagoon varied from $0.01 \mathrm{~m}$ to $1.32 \mathrm{~m}$ above MSL and 0.12 to $1.54 \mathrm{~m}$ above MSL at Kallady and Manmunaithurai area, respectively. Lagoon water starts to enter into the adjacent land upto $13 \mathrm{~m}$ in West and $18 \mathrm{~m}$ in East at Manmunai area when the water height at 0.60 above MSL, whereas, it entered upto $1.1 \mathrm{~m}$ in West and $1.4 \mathrm{~m}$ in East at Kallady when the water height is about $0.55 \mathrm{~m}$ above MSL on 17.12.2012. Also it was observed that, during the heavy rain (total amount of rainfall was $330.9 \mathrm{~mm}$ ) that occurred during 15.12.2012 to 18.12.2012, the lagoon water entered the adjacent land upto $48 \mathrm{~m}$ (West side), $30 \mathrm{~m}$ (East side) at Kallady and $56 \mathrm{~m}$ (East) $45 \mathrm{~m}$ (West) from the lagoon border at Manmunai thurai when the lagoon water height of $1.32 \mathrm{~m}$ and $1.54 \mathrm{~m}$ above MSL at the flood gauges fixed at Kallady and Manmunai thurai area, respectively. At the time of this event, adjacent roads (Lady manning road, lake road etc) and portion of the land area of the households at Kallady area were flooded and disturbed the livelihood. Similarly, Manmunaithurai road were flooded (average depth of flood water at the road were $0.78 \mathrm{~m}$ ) and the transport to the villages located at the west side of the lagoon were completely blocked for two days. Ferry services also stopped for nearly one week at Manmunaithurai area. About 40 acres of paddy land situated along the lagoon border at Manmunai thurai area were affected during that period. Then the bar mouth was deepened to drain the lagoon water when the lagoon water height at Kallady was $1.32 \mathrm{~m}$ above MSL.

\section{Variation of Lagoon water height with the rainfall amount}

The variation of lagoon water height with the rainfall amount at both study area are given in Fig. 3 . 


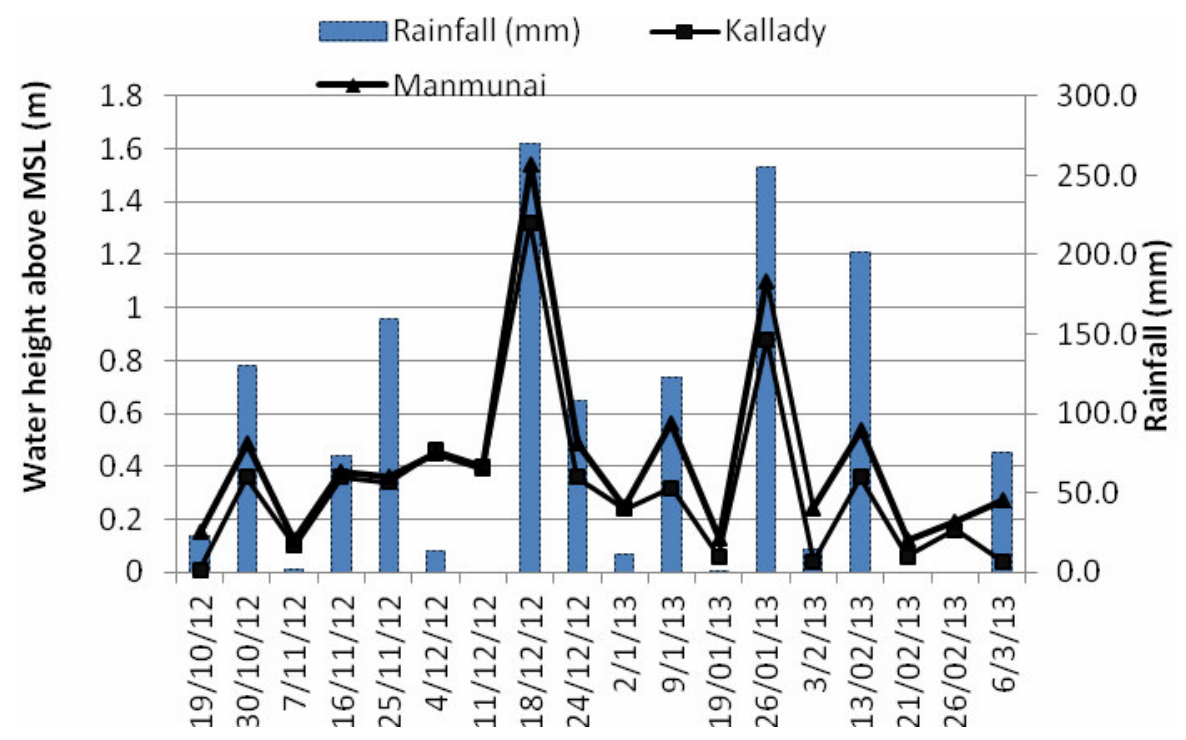

Fig. 3. Variation of lagoon water height from MSL with amount of rainfall

As shown in Fig. 3, lagoon water height was lowest at Kallady area ( $0.1 \mathrm{~m}$ above MSL) at the beginning of the wet season. Water depth was reached as highest at both study sites when the rainfall received from 15.12.2012 to 18.12.2012. The correlation $\left(r^{2}=0.73\right.$ and $r^{2}=0.75$ at Kallady and Manmunaithurai, respectively) was found in between the rainfall and the lagoon water height as shown in Fig. 4. Because, the water height of the lagoon varied due to the direct contribution from high amount of rainfall $(217.5 \mathrm{~mm}, 365.4 \mathrm{~mm}, 661.4 \mathrm{~mm}, 786.8 \mathrm{~mm}$ and 300mm during October 2012, November 2012, December 2012, January 2013 and February 2013 respectively), water inflow from adjacent tanks like Unnichchai, Navagiri and also the tidal action of sea at later part of the rainy season. 

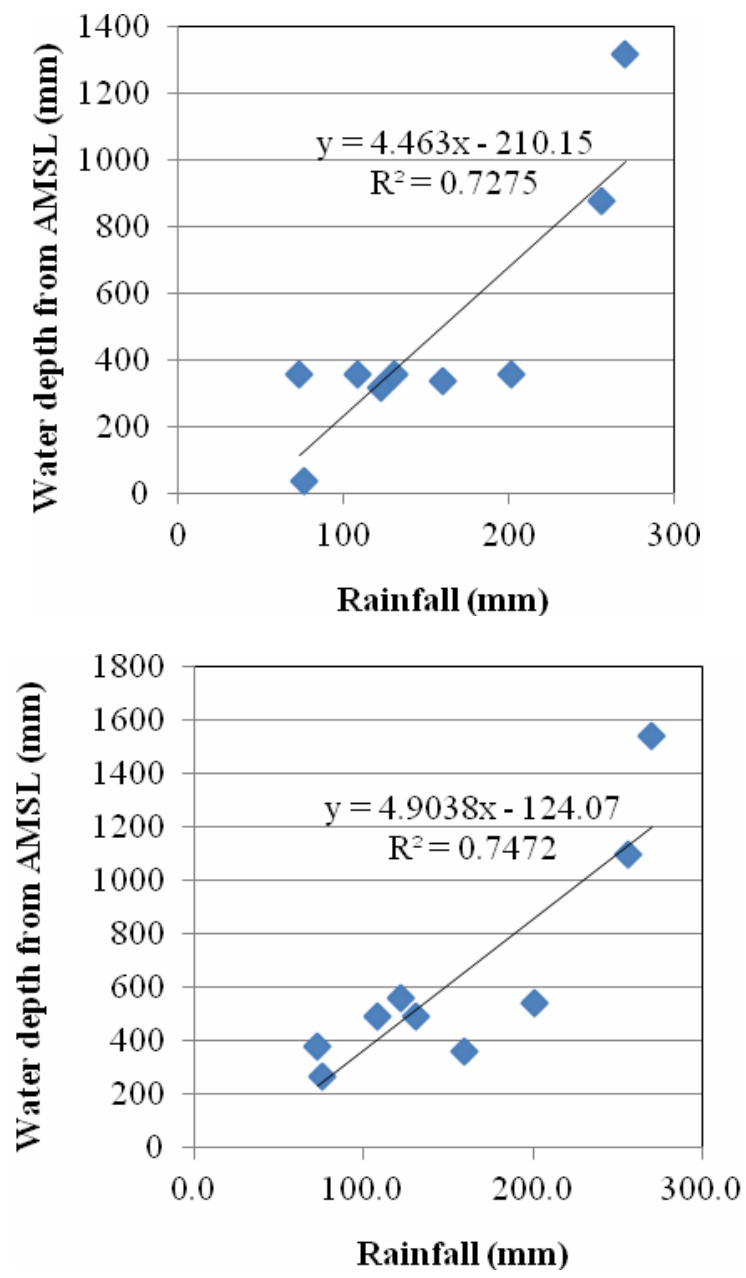

Fig. 3. Relation between the rainfall and water level in Kallady (Above) and Manmunai (Below)

\section{Temperature}

Temperature is a critical factor influencing several aspects of the lagoon ecosystem. It influences biological activity and many chemical variables in the lagoon. Many estuarine organisms can tolerate gradual temperature changes associated with changing seasons, but sudden changes can cause stress (Matthew \& Catherine 2004). The lagoon water temperature at the surface of the lagoon at Kallady and Manmunai during October 2012 to March 2013 ranged from 25.1 to $30.6{ }^{\circ} \mathrm{C}$. Lowest temperature was recorded at Kallady area during the peak rainfall period. These variations may be due to the change of atmospheric temperature and wind action within the lagoon environment during day and night. 
pH

The Fig. 4 shows the fluctuation of $\mathrm{pH}$ during the monitoring period. The $\mathrm{pH}$ values varied within a narrow range; the highest $\mathrm{pH}$ value of 8.68 was recorded at Kallady on 26.01.2013, whereas the lowest (7.7) was recorded at Manmunai area. There was no correlation found between rainfall and the $\mathrm{pH}$.

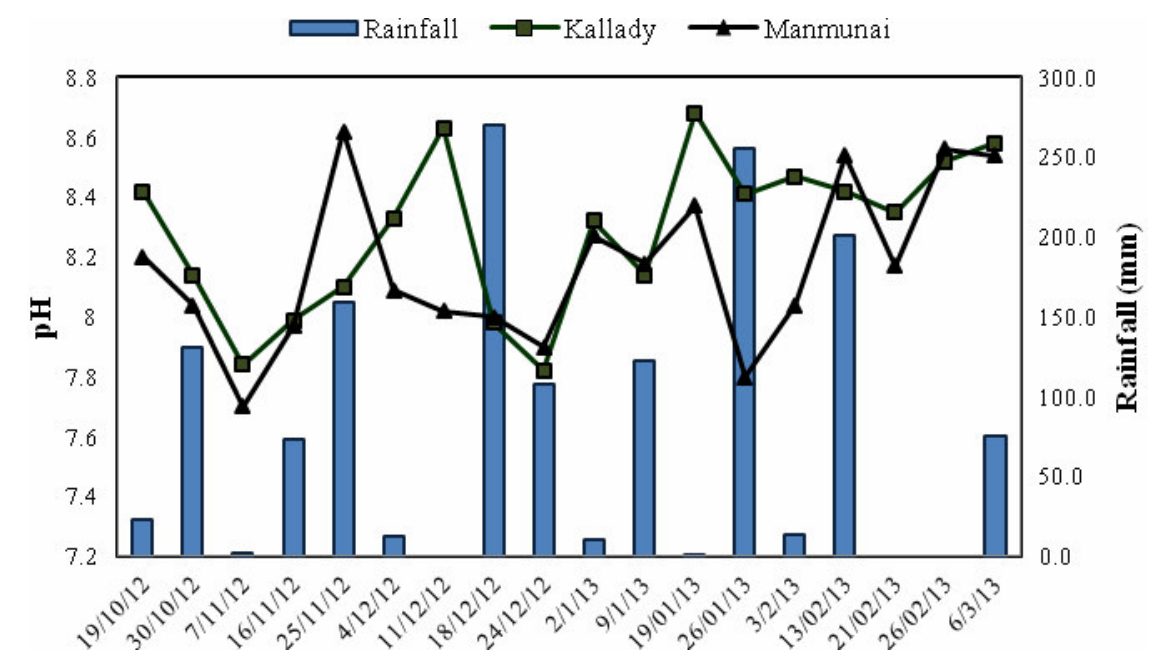

Fig. 4. Lagoon water $\mathrm{pH}$ during rainy season

\section{Variation of EC, TDS and Salinity}

As far as both study sites is concerned, EC values of the Batticaloa lagoon fell in between 0.2 to $39.9 \mathrm{dS} / \mathrm{m}$ (Fig. 5). Similarly, Salinity levels (Fig. 6) were found as 0.1 to $19.9 \mathrm{ppt}$ and 2.5 to $37.5 \mathrm{ppt}$, respectively.

Salinity in the Batticaloa lagoon comes from the ocean. Therefore, the area (Kallady) closer to the ocean have higher salinities. Significant increase of salinity in the lagoon water was recorded during 02.01.2013, 26.02.2013 and after 21.03.2013 due to salt water intrusion from ocean near Kallady area and lack or no rainfall during that period. Whereas, significant increase in salinity of lagoon water at Manmunai was observed on 08.04.2013 (Table 1). Therefore, it reveals that, it takes nearly 16 days to reach from Kallady to Manmunai area. During the later part of the dry season, salinity was high at both locations as salty water intrudes further up into the lagoon and higher evaporation rate at lagoon area, while, salinity decreased during the rainy period (October 2012 to February 2013).

Large variation in salinity is mainly linked to the opening of sluice of Unnichchai tank and other minor tanks linked with the lagoon environment to drain the excess rainwater during high rainfall intensity 


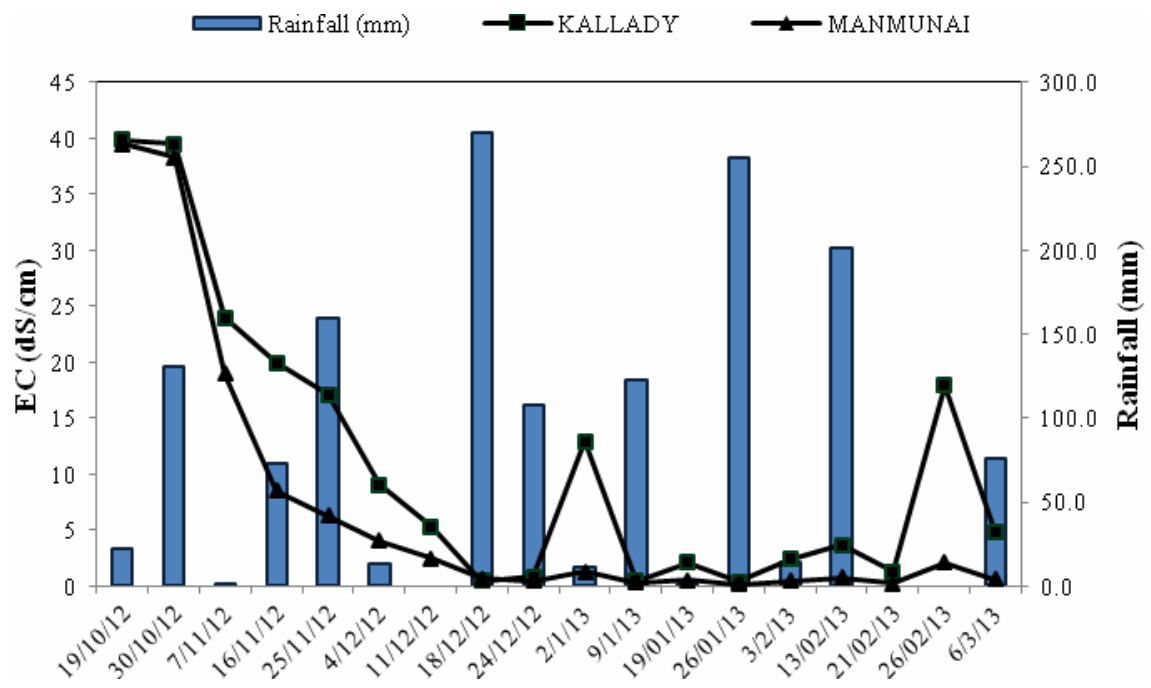

Fig. 5. Variation of Electrical Conductivity (EC) with rainfall

Table 1. Variation of salinity with the rainfall during initial period of dry season at study area

\begin{tabular}{lccccc}
\hline & & \multicolumn{2}{c}{ Kallady } & \multicolumn{2}{c}{ Manmunaithurai } \\
\cline { 3 - 6 } Date & $\begin{array}{c}\text { Rainfall } \\
(\mathbf{m m})\end{array}$ & $\begin{array}{c}\text { water height }(\mathbf{m}) \\
\text { from MSL }\end{array}$ & $\begin{array}{c}\text { Salinity } \\
\text { (ppt) }\end{array}$ & $\begin{array}{c}\text { water height (m) } \\
\text { from MSL }\end{array}$ & $\begin{array}{c}\text { Salinity } \\
\text { (ppt) }\end{array}$ \\
\hline $14 / 03 / 13$ & 15.9 & 0.16 & 4.5 & 0.19 & 3.5 \\
$21 / 03 / 13$ & 0.0 & 0.17 & 11.0 & 0.14 & 4.0 \\
$28 / 03 / 13$ & 26.2 & 0.2 & 16.0 & 0.18 & 4.0 \\
$08 / 04 / 13$ & 0.0 & 0.06 & 23.6 & 0.08 & 6.9 \\
$15 / 04 / 13$ & 0.0 & 0.03 & 23.6 & 0.04 & 4.5 \\
\hline
\end{tabular}

\section{CONCLUSIONS}

The lagoon water levels varied between 0.01 and $1.32 \mathrm{~m}$ above mean sea level (AMSL) at Kallady, which is located near the barmouth, whereas the variation at Manmunaithurai was between 0.12 and $1.54 \mathrm{~m}$. Correlation was found between the rainfall and the lagoon water height ( $\mathrm{r}=0.782$ and $\mathrm{r}=0.853, \mathrm{p}<0.01$ at Kallady and Manmunaithurai area, respectively). Salinity variation was from 3.0 to $37.5 \mathrm{ppt}$ and 2.5 to $31.0 \mathrm{ppt}$ at Kallady and Manmunaithurai, respectively. Salinity showed a decreasing trend with time during the rainy season. The variation was mainly due to the dilution of the lagoon water by rainwater during the rainy season and the salt water intrusion at the later part of rainy season. Further, salinity of this coastal lagoon mainly comes from the tidal action. Therefore, areas closer to the sea have higher salinities.The study revealed that a substantial variation in salinity occurs 
during a short period during the wet season and warrants further investigation on its influence on ecosystem and livelihoods.

\section{REFERENCES}

Andreoli Remi,. Jiren, L.I, Yesou Herve (2007) Flood extent prediction from lake heights and water level estimation from flood extents using river gauges, elevation models and Envisat data. Proc. 'Envisat Symposium 2007'. Montreux, Switzerland 23-27 April 2007 (ESA SP-636, July 2007)

Furusato, E, Amarasekara, G.P. Priyadarshana T.and Tanaka N. (2012), The current status of density stratification of Koggala lagoon. ACEPS- 2012.

Knoppers, B., Kjerfve, B and Carmouze ,J., 1991. Trophic state and water turn-over time in six choked coastal lagoons in Brazil. Biogeochemistry, 14, 149-166.

Matthew, H and Catherine, W. (2004) Continuous water quality monitoring in the Maryland Coastal Bays. 2004 Annual Report, Maryland Department of Natural Resources p 6

MG Consultants (2010), A Bathymetric Survey of Batticaloa Lagoon, Final Report, , Annex 2, June 2010, NEC/PO/TECS(II)/08/12, NECCDEP/ MG Consultants, ADB Loan 2027 (SF): North East Coastal Community Development Project (NECDEP). pp 27

Perera, G.L, Eiichi Furusato,. Amarasekara, G.P Priyadarshana T.and Tanaka N. (2013), Current status of Salinity stratification of Rekawa Lagoon, Sri Lanka. Special session on Sustainable Earth. SLJCR 2013.

Santharuban, S and Manobawan. M (2005), Evaluating the Impacts of an Improperly Designed Bridge across the Batticaloa Lagoon In: Water Resources Research in Sri Lanka, Proceedings of the Water Professionals' Day Symposium, October, 2005.

Scot, A.D. (1989). A directory of Asian wetlands. IUCN, The world conservation union, Cambridge, pp: 605-606.

Shanmugaratnam, N. (1995). The need for and steps towards a master plan for suitable utilization of the Batticaloa lagoon. Report to NORAD, pp: 1. 